\title{
EFFECTIVENESS TEST OF ABSORPTION CAPACITY OF ACTIVATED CHARCOAL BY IMMERSING H3P04 AND GRAIN SIZE PALM OIL SHELLS ON INSTALLATION OF PEAT WATER TREATMENT
}

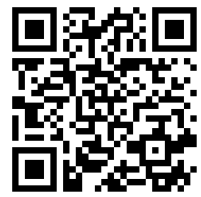

\author{
Diharyo ${ }^{* 1} \bowtie$ \\ ${ }^{* 1}$ Graduate School of Environmental Science, Palangka Raya University, Central Kalimantan, \\ Indonesia
}

DOI: https://doi.org/10.29121/granthaalayah.v8.i5.2020.228

Article Type: Research Article

Article Citation: Diharyo. (2020). EFFECTIVENESS TEST OF ABSORPTION CAPACITY OF

ACTIVATED CHARCOAL BY IMMERSING H3PO4 AND GRAIN SIZE PALM OIL SHELLS ON INSTALLATION OF PEAT WATER TREATMENT. International Journal of Research -GRANTHAALAYAH, 8(5), 383-389.

https://doi.org/10.29121/granthaa layah.v8.i5.2020.228

Received Date: 16 May 2020

Accepted Date: 31 May 2020

Keywords:

Activated Charcoal

Installation

Palm Oil Shell

Peat Water

$\mathrm{H}_{3} \mathrm{PO}_{4}$

\section{ABSTRACT}

Peat water is one of the ground or surface water found in swampy and lowland peat areas, brownish red, high acidity, and has high organic content. Palm shells activated charcoal can be useful as a raw material for making activated carbon because it is very effective at absorbing organic content in peat water, testing the effectiveness of peat water treatment installation with activated arbons is one way to determine the adsorption power of activated charcoal against peat water contaminants. The aim of this study was to determine the absorption capacity of activated charcoal by immersing H3PO4 and grain size of mesh 200 palm oil shells through the effectiveness test of peat water treatment installation. The variables observed with the effectiveness test of peat water treatment installation were $\mathrm{pH}$ and iron content (Fe). Analysis of the data used is descriptive analysis that compares before and after treatment of peat water with activated carbon. From the measurement results of peat water parameters compared with the quality standards of the Regulation of the Minister of Health of the Republic of Indonesia Number 492 of 2010 concerning Drinking Water Quality. The results of testing the effectiveness of peat water installation with activated charcoal as a result of activation by immersion using Phosphoric Acid (H3PO4) with a grain size of palm shell charcoal of 200 mesh can improve the quality of peat water but do not meet clean water quality standards that are fit for drinking. An increase in peat water $\mathrm{pH}$ from 4.443 to 6.4 - 6.5, and a decrease in Fe content from $9.43 \mathrm{mg}$ / l to $2.275-3.309 \mathrm{mg} / \mathrm{l}$.

\section{INTRODUCTION}

Peat water is one of the ground or surface water found in swampy and lowland peat areas, brownish red, high acidity, and has high organic content. Peat is defined as organic material that is formed from imperfect decomposition of plants in wet areas and in very humid conditions and lack of oxygen. Peat water in general does not meet clean water quality requirements.

The palm shell has many uses and benefits for the business and household industries. Some of them are high economic value products, namely activated charcoal, liquid smoke, phenols, charcoal briquettes, and shell flour. Palm shells are the hardest part of the components found in oil palm. Judging from the characteristics of the raw materials, when compared to ordinary coconut shells, oil palm shells have many similarities. A striking difference is the ash

(C) 2020 The Author(s). This is an open access article distributed under the terms of the Creative Commons Attribution License, which permits unrestricted use, distribution, and reproduction in any medium, provided the original author and source are credited. 
Effectiveness Test of Absorption Capacity of Activated Charcoal by Immersing H3po4 and Grain Size Palm Oil Shells on Installation of Peat Water Treatment

content which usually affects the quality of products produced by coconut shells and palm shells. Charcoal is a porous solid material which is the result of combustion of materials containing carbon elements (Djatmiko, 1985), while activated charcoal is charcoal that is activated by immersion in chemicals so that the pores of the material become more open to the surface area.

Activated carbon pores need to be activated so that the performance in adsorption is more optimal. The purpose of the activation process is to increase or enlarge the carbon pore diameter and develop the volume absorbed in the pore and to open new pores (Prabarini and Okayadnya, 2014). Activation is a process of forming activated carbon that functions to add, open and develop carbon pore volume and can increase the diameter of carbon pores that have been formed from the carbonization process through chemical or physical methods. (Budiono et al, 2009; Kurniawan, 2014).

The wider surface of activated charcoal has an impact on the increased absorption of gas or liquid material (Kirk and Othmer, 1964). Absorption of activated charcoal is very large, which is $25-1000 \%$ of the weight of activated charcoal. Because of this, active charcoal is widely used by industry. Nearly $60 \%$ of the production of activated charcoal in the world is utilized by the sugar industries and cleaning oil and fats, chemicals and pharmaceuticals (Arifin, 2008). According to Hendra (2010) there are generally three activation processes for charcoal, including physical, chemical and physics-chemical combinations. The physical activation process is carried out by burning charcoal in a furnace with a temperature of $850 \mathrm{OC}$. The chemical activation process is carried out by adding certain chemical compounds to the charcoal. Chemical compounds that can be used as activating agents include $\mathrm{KCl}, \mathrm{NaCl}$, $\mathrm{ZnCl}_{2}, \mathrm{CaCl}_{2}, \mathrm{MgCl}_{2}, \mathrm{H}_{3} \mathrm{PO}_{4}, \mathrm{Na}_{2} \mathrm{CO}_{3}$, and other mineral salts. The optimum conditions for making activated charcoal with the best quality from the raw material of palm oil shell is at a temperature of $850 \mathrm{OC}$. The results of Faradina and Setiawati's (2010) research stated that the charcoal is activated by using a chemical compound, namely $\mathrm{ZnCl}_{2}$. According to Prasetyani (2010) the activation of active kabron is done by adding $\mathrm{ZnCl} 2$, as an activator so that the surface pores of the charcoal become wider. This will facilitate the absorption process. Activated charcoal is used to remove impurities by absorbing or adsorping. The ability to absorb impurities is an indicator of the success rate of the activated charcoal process.

Charcoal can be used as fuel and can be used as an adsorbent (absorbent) in the gas separation process. Absorption of contaminants in water, recovery solvent, catalyst and catalyst support. In use as an adsorbent, the absorption of charcoal is determined by the surface area of the pore. The wider surface of the charcoal results in a higher absorption of gas or liquid (Kirk and Othmer, 1964). The absorption ability of charcoal can be higher if the charcoal is activated with chemicals or by heating at high temperatures. Activated charcoal will experience changes in physical and chemical properties called activated charcoal (Meilita and Tuti, 2003).

Activated charcoal is charcoal that is activated by immersion in chemicals or by flowing hot steam into the material, so that the pores of the material become more open to the surface area. Activated charcoal can be made from porous carbon material which can be obtained from agricultural solid waste materials such as rice husks, coconut shells, palm shells, candlenut shells and urban solid waste materials such as plastics, paper and cardboard. One of the solid waste materials from plantations that are still underutilized is palm shells. In general, companies make palm oil shells as waste materials with little use. On the other hand, the palm shell also has the prospect as a raw material for making activated charcoal.

The activated carbon properties themselves are not only influenced by the type of raw material, surface area, pore distribution and surface chemical characteristics of activated charcoal, but also influenced by the activation method used (Austin, 1984). According to Girgis et al. (2002) suggested that H3PO4 as an activation agent would give the best results when compared with $\mathrm{ZnCl} 2$ and $\mathrm{KOH}$. These activating agents are dehydrators which can reduce the remaining $\mathrm{OH}$ and $\mathrm{CO}$ from the carbonized carbon. Therefore, it is necessary to do activation by immersing using H3PO4 on several sizes of palm shell charcoal grains to get the surface area of activated charcoal grains.

This research was conducted to find out the activated absorbability of activated charcoal by immersing H3PO4 and grain size of 200 mesh palm oil shells against peat water contaminants through the effectiveness test of peat water treatment installation. 


\section{MATERIALS AND METHODS}

Diharyo

The raw material used in this research is the Dura Palm Oil (Elais guneensis Jacg) type on PT. Surya Cipta Perkasa, Sebangau Kuala District, Pulang Pisau Regency, Central Kalimantan Province, Phosphoric Acid solution $\left(\mathrm{H}_{3} \mathrm{PO}_{4}\right)$, $\mathrm{Peat}$ Water as much as 5 liters and a set of peat water treatment plants.

The method of making activated charcoal is done by making charcoal and activating the charcoal that has been made. The making of charcoal from palm shells is done by washing the palm shells and then drying them in the sun. Each charcoal material is put into a charcoal furnace and heated at a temperature of 500 oC for 5 hours. Writing is considered complete when the smoke emitting from the chimney is thin and bluish in color. Activation of oil palm shell charcoal can be done by means of oil palm shells that have been made crushed charcoal to obtain the desired grain size or dimensions of charcoal. The charcoal is filtered by sieve analysis with a retained size of a 200-mesh filter.

After obtaining charcoal with dimensions and size of 200 mesh, then the charcoal is activated by immersing it in a $2.5 \%$ Phosphoric Acid $\left(\mathrm{H}_{3} \mathrm{PO}_{4}\right)$ solution as an activator. The immersion activation time is carried out with a 16-hour immersion duration.

From the activation of activated charcoal above, then washed using distilled water so that it reaches a neutral pH. Furthermore, the activated charcoal is dried in the oven for 1 hour at a temperature of $120 \mathrm{oC}$ and the activated charcoal is ready to be tested for the effectiveness of peat water treatment installation. Installation of vertical peat water treatment test is presented in Figure 1.

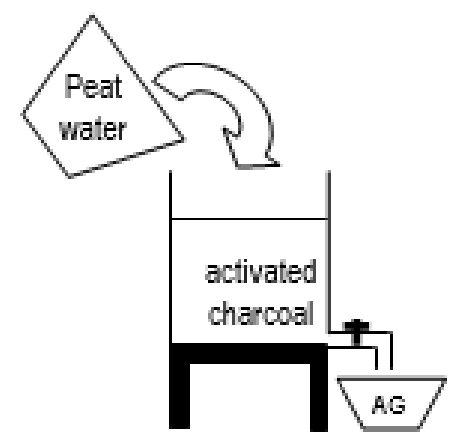

Figure1: Installation of vertical peat water treatment

The variables observed with the effectiveness test of peat water treatment installation were $\mathrm{pH}$, iron (Fe) content, and the analysis of the data used was descriptive analysis, which compares before and after peat water treatment with activated carbon. From the measurement results of peat water parameters compared with the quality standards of the Regulation of the Minister of Health of the Republic of Indonesia Number 492 of 2010 concerning drinking water quality. To test the effectiveness of a complete treatment tool in reducing iron $(\mathrm{Fe})$ and $\mathrm{pH}$ in peat water using the formula:

$$
\text { Effectiveness }=\frac{(\mathrm{A}-\mathrm{B})}{\mathrm{A}} \times 100 \%
$$

Where:

$\mathrm{A}=$ iron $(\mathrm{Fe}) / \mathrm{pH}$ before treatment

$\mathrm{B}=$ iron $(\mathrm{Fe}) / \mathrm{pH}$ level after treatment

\section{RESULTS AND DISCUSSION}

\subsection{EFFECTIVENESS TEST RESULTS OF PEAT WATER INSTALLATION WITH ACTIVE CHARCOAL}

The results of testing the effectiveness of peat water installations with activated charcoal are presented in Table 1.

Table 1: Effectiveness Test Results for Each Parameter from Peat Water Samples

\begin{tabular}{|c|c|c|c|c|c|}
\hline No. & Parameter & Unit & Peat water & $\begin{array}{c}\text { Peat water effectiveness test results } \\
\text { after the addition of activated charcoal }\end{array}$ & Quality standards \\
\hline
\end{tabular}

International Journal of Research -GRANTHAALAYAH 
Effectiveness Test of Absorption Capacity of Activated Charcoal by Immersing H3po4 and Grain Size Palm Oil Shells on Installation of Peat Water Treatment

\begin{tabular}{|c|c|c|c|c|c|c|}
\hline & & & & 1 & 2 & \\
\hline 1 & Color & TCU & Brown & Yellow & Yellow & Colorless \\
\hline 2 & Smell & & Smells & Smells & Smells & Colorless \\
\hline 3 & Taste & & Acid & alkaline & alkaline & alkaline \\
\hline 4 & Turbidity & NTU/FAU & 0,93 & 23,10 & 33,00 & - \\
\hline 5 & DOC & $\mathrm{Mg} / \mathrm{l}$ & 65.15 & 46,54 & 44,98 & - \\
\hline 6 & Temperature & $\mathrm{C}$ & 27 & 27 & 27 & \\
\hline 7 & DO & $\mathrm{Mg} / \mathrm{l}$ & 9,04 & 6,94 & 5,71 & 1000 \\
\hline 8 & TDL & & 193,10 & 654 & 624 & - \\
\hline 9 & $\mathrm{pH}$ & & 4,443 & 6,500 & 6,400 & $6,5-8,5$ \\
\hline 10 & $\mathrm{CaCO}_{3}$ & $\mathrm{mg} / \mathrm{l}$ & 357,12 & 1228,51 & 571,40 & 500 \\
\hline 11 & Florida & $\mathrm{mg} / \mathrm{l}$ & 0,502 & 1,099 & 1,157 & 1,5 \\
\hline 12 & Fenol & $\mathrm{mg} / \mathrm{l}$ & 0,011 & 0,058 & 0,064 & - \\
\hline 13 & Iron & $\mathrm{mg} / \mathrm{l}$ & 9,430 & 3,309 & 3,275 & 1,0 \\
\hline 14 & Copper & $\mathrm{mg} / \mathrm{l}$ & 0,005 & 0,027 & 0,034 & - \\
\hline 15 & Manganese (Mn) & $\mathrm{mg} / \mathrm{l}$ & 0,160 & 0,148 & 0,154 & 0,4 \\
\hline 16 & Calcium & $\mathrm{mg} / \mathrm{l}$ & 0,174 & 1.926 & 1,643 & - \\
\hline
\end{tabular}

Source: Research Results, 2019

In general, after analyzing data using descriptive analysis, comparing before and after processing of peat water with activated carbon, shows that there are changes in the initial characteristics of peat water, namely iron (Fe) and $\mathrm{pH}$ levels for peat water do not meet the quality standards based on regulations Minister of Health of the Republic of Indonesia Number 492 of 2010 concerning Drinking Water Quality. Therefore, the use of peat water for daily needs without community treatment will have a negative impact on health.

Measurement of $\mathrm{Fe}$ (iron content) from the peat water treatment plant using activated charcoal with repetition 2 times, showing that the iron content from $9.43 \mathrm{mg} / \mathrm{l}$ decreased to 2.275-3309 $\mathrm{mg} / \mathrm{l}$. The effectiveness of decreasing iron $(\mathrm{Fe})$ content in the peat water treatment process using a peat water treatment plant with activated charcoal is very large, its effectiveness reaches 76.14\%. Based on the results of these measurements it can be stated that the iron content of the complete treatment process of peat water with activated charcoal still does not meet the quality standards in accordance with the Regulation of the Minister of Health of the Republic of Indonesia Number 492 of 2010, because the water quality standard for minimum is $1 \mathrm{mg} / \mathrm{l}$. The decrease in Fe levels is caused by the presence of activated carbon as a filter so that the adsorption process occurs. Adsorption is the absorption of a substance (molecule or ion) on the surface of the adsorbent. The adsorption power of activated carbon is due to the fact that activated carbon has an open pore. This pore causes the surface of activated carbon to become wider. This statement is supported by the opinion of Nugroho (2008), that a broad surface of the adsorbent occurs because carbon has a hollow internal surface. Messayu (2009) added that the increase in activated carbon mass is proportional to the increase in the number of particles and surface area of activated carbon, causing the number of sites to bind metal ions to increase and the adsorption efficiency to increase.

Iron (Fe) is a chemical element that can affect water quality. Decreased levels of iron (Fe) that are too high in water can cause water to color and smell. After the peat water treatment process is carried out using a peat water treatment plant with activated charcoal proportional to the change in color which was originally brown to turn yellow due to a decrease in iron (Fe) level of 76.14\%. This opinion is supported by Suhartana (2006), that generally activated charcoal is used as an absorbent and purifier. In small quantities it is also used as a catalyst. The adsorption properties are selective, depending on the size or volume of the pores and surface area. Absorption of activated charcoal is very large, which is $25-100$ percent to the weight of activated charcoal. Activated charcoal can absorb particles that can cause odor and taste in water, so as to eliminate odors and flavors in the water.

The initial $\mathrm{pH}$ value of peat water is acidic with a $\mathrm{pH}$ value of 4.443. After the peat water is processed using a peat water treatment plant with activated charcoal, the $\mathrm{pH}$ of the water has increased to alkaline with a $\mathrm{pH}$ value of 6.4 - 6.5 approaching normal. The effectiveness of increasing $\mathrm{pH}$ in the process of peat water treatment using peat water treatment plants with activated charcoal is $47.72 \%$ effectiveness. When compared with the drinking water quality standard of 6.5-8.5, the peat water from the installation using activated charcoal can improve the quality of peat water from acidic to alkaline and meet the quality standard according to the Minister of Health Regulation of 
the Republic of Indonesia Number 492 of 2010 This statement is supported by the opinion of Hysocc (2013), that $\mathrm{pH}$ is the degree of acidity used to express the acidity or basicity of a solution. PH values below 7 are acidic and above 7 are alkaline. Water can be consumed by the community if the $\mathrm{pH}$ of the water is within the range of drinking water quality standards. Acidic water can cause itching, diarrhea and scaly skin (Suhendra et al, 2012). Based on the results obtained, it can be seen that the filtration process with activated charcoal has decreased the pH value with the alleged filtration process with a filter can reduce the $\mathrm{pH}$ value of water. Whereas in the filtration process with the addition of activated charcoal, the $\mathrm{pH}$ value is quite high, thus apart from being used as an absorbent, it is suspected that activated charcoal can also be used to increase the $\mathrm{pH}$ value in water. Thus, it can be said that the filtration process by adding activated palm shells (Elaeis guineensis) is good enough to improve acidic water quality. This statement is supported by the opinion of Suhartana (2006), that a decrease in the $\mathrm{pH}$ value of water after being given coconut fiber charcoal filtrate, because coconut coir charcoal also contains calcium carbonate salts, which at certain times will be able to dissolve in water.

From the results of the peat water treatment plant using activated charcoal although it can improve the acidic $\mathrm{pH}$ to alkaline, but the iron (Fe) content is still relatively large and does not meet clean water quality standards in accordance with the Regulation of the Minister of Health of the Republic of Indonesia Number 492 of 2010, but there are improvement of peat water quality.

\section{CONCLUSIONS AND RECOMMENDATIONS}

\subsection{CONCLUSIONS}

The results of testing the effectiveness of peat water installation with activated charcoal as a result of activation by immersion using Phosphoric Acid (H3PO4) with a grain size of palm shell charcoal of 200 mesh can improve the quality of peat water but do not meet clean water quality standards that are fit for drinking. An increase in peat water pH from 4.443 to 6.4 - 6.5, and a decrease in Fe content from $9.43 \mathrm{mg} / \mathrm{l}$ to 2.275 - $3.309 \mathrm{mg} / \mathrm{l}$.

\subsection{RECOMMENDATIONS}

Based on the results of this study it is recommended that the use of peat water for daily life needs to be treated first if it will be used by the community, so it does not have a negative impact on health.

\section{SOURCES OF FUNDING}

None.

\section{CONFLICT OF INTEREST}

The authors declared that the present study was performed in the absence of any conflict of interest.

\section{ACKNOWLEDGMENT}

Thanks to various parties, namely (1) Parents, Wives and children who are always supporting in completing their S3 education, (2) CIMTROP Palangka Raya University (UPR) who are willing to facilitate Research activities, (3) General Manager of PT. Surya Cipta Perkasa who helped carry out research in the field, (4) Head of Forest Product Management Laboratory, Department of Forestry, Faculty of Agriculture, University of Palangka Raya (UPR), Head of Advanced Material Processing Laboratory, LIPI, Integrated Laboratory of Palangka Raya University (UPR) who was willing to facilitate equipment research.

\section{AUTHOR CONTRIBUTIONS}

D, S and ZD design and conduct research, data collection, data analysis and also manuscript writing. SG, S designs and conducts research, reviewing manuscripts and submit manuscripts. 
Effectiveness Test of Absorption Capacity of Activated Charcoal by Immersing H3po4 and Grain Size Palm Oil Shells on Installation of Peat Water Treatment

\section{REFERENCES}

[1] Austin, G.T.,1984, Shreve's Chamical Process Industry, Fifth Edition. Mcgraw Hill Book Company, Newyork, page136-138.

[2] Mun'in, A. and Bardi M. 1999. Making Activated Carbon from Peat soils. East Java: UPN Industrial Technology Faculty.

[3] Arifin. 2010, Water Decolorization Containing Textile Dyes Using Poly Aluminum Chloride Coagulation Method and Active Charcoal Adsorption. Tangerang: PT. Tirta Kencana Cahaya Mandiri.

[4] Astuti. 1990. Effectiveness of Active Charcoal as Adsorbent in Wastewater Treatment, Medan: University of North Sumatra.

[5] Astuti, D. M. 1990. Activation of Coconut Shell Carbon with the addition of Sodium and Potassium Halide (Skripsi). Faculty of Mathematics and Natural Sciences UGM. Yogyakarta

[6] BPPI. 1980. Making Activated Carbon from Peat soils. East Java: UPN Industrial Technology Faculty.

[7] Buekens, A. Keirsse, H. Schoeters, J. and Verbeeck, A. 1985. Production of Actived Carbon from Euphorbia Tiracull. Brussel.

[8] Cheremisinoff, N. P. 1993. Carbon Adsorption of Pollutant Control. John Willey \& Sons Canada.

[9] Djatmiko, 1985. Processing of Charcoal and its Use. Department of Agricultural Product Technology. Faculty of Agricultural Technology. Bogor Agricultural Institute. Bogor

[10] Faradina, E. dan Setiawati, N. 2010. Cooking Oil Regeneration with Bleaching Process Using Active Charcoal Adsorbent, Research Report on Chemical Engineering Study Program, Faculty of Engineering, Lambung Mangkurat University, Banjarbaru.

[11] Girgis, B.S. Samya, S.Y. Ashraf, M.S. 2002. Characteristic of Activated Carbon from Peanut Hulls in Relation to Condition of Preparation, Materials Letters, hal 57(1).

[12] Hassler, J.W. 1974. Purification with Actived Carbon: Industrial Commercial, Environmental. Chemical Publishing Co. Inc, New York.

[13] Hendra (2010). The Nature of Active Charcoal from Candlenut Shells. Journal of Forest Products Research, 25 (4): 291 - 302

[14] Hendra and Pari. 1999. Making Active Charcoal and Oil Palm Empty Fruit Bunches. Bulletin of Forest Products Research. Jakarta.

[15] Jankowska, H., Swiatkowski, A., and Choma, J. 1991. “Active Carbon. Horwood”, London.

[16] Joni, T.L. et.al. 1995. Engineering of Making Rice Husk Burning Stoves for Making Active Charcoal from Rice Husk. Industrial Research and Development Center. Ujung Pandang.

[17] Kienle, H.V. Campbell, F.T. Pfefferkom, R. and Rounsaville, J.F., 1986, Ulman's Encyclopedia of Industrial Chemistry. 5th Completely Resived Edition, Volume 5. Cancer Chemotherapy to Ceramics Colorants. VCH, Weinheim.

[18] Kirk and Othmer. 1964. "Encyclopedia of Chemical Technology" Vol.4 Second Edition. USA.

[19] Kurniati. 2008. Utilization Palm Oil Shell As Active Charcoal. East Java: Chemical Engineering UPT FTI.

[20] Lu, W. and Chung, D.D.L. 2001. Preparation of conductive carbons with high surface area. Carbon 39: 39-44

[21] Meilita, T.S. and Tuti, S.S. 2003, Active Charcoal (Introduction and Manufacturing Process), Skripsi, Faculty of Engineering, University of North Sumatra, Medan.

[22] Messayu, P. 2009. Rice Husk Charcoal Waste as Cr (III) and Cr (IV) Adsorbent. Skripsi. Bogor Agricultural Institute. Bogor.

[23] Nugroho, C. 2008. Decrease in Total Suspenend Solid Concentration (TSS) in Lubricating Oil Waste Derived from Workshop by Using Oil and Activated Carbon Separator Reactors and Zeolites as Adsorbents. Final task, Department of Environmental Engineering, Faculty of Civil Engineering and Planning, Islamic University of Indonesia. 31-48.

[24] Pari, G. 1999. Manufacture and characteristics of activated charcoal from coal, Chemistry Masters Program Thesis, Bandung Institute of Technology, Bandung. Unpublished.

[25] Pari et al. 2000. KPossible Utilization of Acacia Mangium Willd Bark Active Charcoal for Refining Palm Oil. Forest Products Research Bulletin. 8(1): 40 - 53. Center for research and development of forest products. Bogor.

[26] Regulation of the Minister of Health of the Republic of Indonesia. 2010. Regulation of the Minister of Health of the Republic of Indonesia Number 492 of 2010 concerning Drinking Water Quality. Jakarta.

International Journal of Research -GRANTHAALAYAH 
[27] Prasetyani. 2010. Making Activated Carbon from Kluwak Seed Skin with ZnCl2 Activation. Diponegoro University. Semarang.

[28] Prameidia, M.D. 2013. The Effect of H2SO4 Activator Concentration on the Absorption of Active Carbon from Palm Oil Shells. http://digilib.polsri.ac.id/gdl.php?mod=browse\&op=read\&=ssptpolsri-gdl-dwimonikap6543

[29] Purwanto, D.. 2011. Charcoal from Palm Oil Shell Waste. Forest Products Research Journal. Banjar Baru.

[30] Rodriguez-Reinoso F., Buss, G.Y. 1993. European Paten EP 0329251 B1.

[31] Salamah, S. 2008. Making Activated Carbon from Mahogany Fruit Skin by Soaking Treatment with KOH Solution. Industrial Technology Faculty, Chemical Engineering Department, Ahmad Dahlan University. Yogyakarta.

[32] Salim, and Sudrajat. 1994. Palm Oil and Various Processing. (http://lordbroken.wordpress.com/2011/01/08/kelapa-sawit-dan-aneka-pengolahannya/

[33] Sani. 2011. Making Activated Carbon from Peat soils. UPN Faculty of Industrial Technology. East Java.

[34] Sembiring, M.T. and Tuti S.S. 2003. Active Charcoal (Introduction and Manufacturing Process). Faculty of Industrial Engineering, University of North Sumatra. Medan.

[35] Sudrajat and S. Soleh. 1994. Technical official of making active charcoal, Center for Forest Product and SocioEconomic Forestry. Bogor.

[36] Suhartana. 2006. Utilization of Coconut Temprung as Raw Material for Active Charcoal and Its Application for Purifying Water in Well in Belor Village, Ngaringan District Grobogan Regency. Periodical Journal of Physics: 1410 - 9662 Vol 9 No 3. Faculty of Math and Science, Diponegoro University. Semarang.

[37] Suhendra, D.S., I. Marsaulina and D.N. Santi. 2012. Analysis of Peat Water Quality and Health Complaints in the community in Pulo Gombut Hamlet, Sukarame Village, Kuala Hulu Subdistrict, Labuhan Batu Utara District, 2012. Ministry of Environmental Health Faculty of Public Health. University of North Sumatra. Medan.

[38] Shreve. 1997. Making Activated Carbon from Peat soils. Faculty of Industrial Technology, UPN, East Java.

[39] Tanaka, K. Aoki, H. Ago, H. Yamake, T. and Okahara, K. 1997. Interlayer Interaction Of Two Graphene Sheets As A Model Of Double Layer Carbon Nanotubes. Carbon 35 (1): 121-125.

[40] Tutik and Faizah, 2001. The Effectiveness of Active Charcoal As An Adsorbent In Wastewater Treatment. University of North Sumatra. Medan. 